\title{
Bibliometric Analysis of Research Articles on Pain in the Elderly Published from 2000 to 2019
}

This article was published in the following Dove Press journal:

Journal of Pain Research

\author{
Yanqiao Zhao ${ }^{1,2, *}$ \\ Ziping Zhang ${ }^{2,3, *}$ \\ Suimin Guo ${ }^{2}$ \\ Beibei Feng (iD ${ }^{2,4}$ \\ Xiaoyu Zhao ${ }^{2,5}$ \\ Xueqiang Wang (iD) ${ }^{1,6}$ \\ Yuling Wang (iD ${ }^{2}$

\begin{abstract}
'Department of Sport Rehabilitation, Shanghai University of Sport, Shanghai, of Rehabilitation Medicine, The Sixth Affiliated Hospital, Sun Yat-Sen University, Guangzhou, People's Republic of China; ${ }^{3}$ School of Kinesiology, Shenyang Sport University, Shenyang, People's Republic of China; ${ }^{4}$ Department of Orthopaedics \& Traumatology, The University of Hong Kong, Hong Kong SAR, People's Republic of China; ${ }^{5}$ Department of Optometry, Fenyang College of Shanxi Medical University, Shanxi, People's Republic of China; ${ }^{6}$ Department of Rehabilitation Medicine, Shanghai Shangti Orthopaedic Hospital, Shanghai, People's Republic of China
\end{abstract} \\ People's Republic of China; ${ }^{2}$ Department
}

*These authors contributed equally to this work

Correspondence: Xueqiang Wang Department of Sport Rehabilitation, Shanghai University of Sport, 399

Changhai Road, Yangpu District, Shanghai, People's Republic of China

Email wangxueqiang@sus.edu.cn

Yuling Wang

Department of Rehabilitation Medicine,

The Sixth Affiliated Hospital, Sun Yat-Sen

University, No. 26, Erheng Road, Yuancun,

Tianhe District, Guangzhou, People's

Republic of China

Tel +86-20-38476737

Email wangyul@mail.sysu.edu.cn
Background: Given the rapid growth of the global aging population, pain has become an unneglectable concern amongst the elderly. The quantity of scientific research outputs on pain in the elderly has increased over time, but only a small number of studies have used bibliometric methods to analyze scientific research in this field. This paper aimed to analyze scientific research on pain in the elderly published from 2000 to 2019 in a systematic manner using bibliometric methods.

Methods: Articles on pain in the elderly published from 2000 to 2019 were retrieved from the Web of Science (WoS). Abstracts were coded on the basis of predetermined items (eg, type of article, topic, type of subjects, pain characteristics), and relevant information on the first author, citation scores, and article keywords were collected.

Results: A total of 2105 articles were included in this study. Statistical analysis revealed that the publication of articles on pain in the elderly increased in frequency over time $(\mathrm{P}<0.001)$. Most of the publications were original articles. Amongst the countries identified, the United States published the largest number of papers on this topic. Pain characteristics $(50.21 \%)$, pain intervention $(35.68 \%)$, and pain assessment $(9.69 \%)$ were the main topics of research on geriatric pain. Back pain (12.30\%) appeared to be the most popular pain type described in the included papers.

Conclusion: This work provides researchers with an in-depth understanding of pain in the elderly by evaluating relevant publications in the past two decades. Researchers in this field are warranted to explore future directions on geriatric pain such as the transition from acute pain to chronic pain and the underlying mechanisms of pain in the elderly.

Keywords: elderly, pain, bibliometric analysis

\section{Introduction}

The elderly population is the fastest growing population in modern society. By 2050 , one in six people in the world will be over 65 years old $(16 \%)$, while this number was one in eleven $(9 \%)$ in $2019 .{ }^{1}$ Related to the physiological characteristics of age group, the incidence of many diseases has increased and led to various dysfunctions in the elderly. ${ }^{2}$ Various conditions amongst the older persons are related to or accompanied by pain, such as musculoskeletal diseases, ${ }^{3}$ cancer ${ }^{4}$ and diabetes, ${ }^{5}$ all of which may increase the risk of pain in the elderly.

The prevalence of pain in the elderly, especially chronic pain, is fairly high (estimated at 25-85\%), ${ }^{6,7}$ compared with that in younger group of adults (estimated at $7.3-68 \%$ in the age range of $40-66$ years $)^{8}$ and in children and adolescents (estimated at $11-38 \%$ ). ${ }^{9}$ Thus, pain in the elderly is an issue worthy of concern. It is crucial for healthcare professionals to assess the pain of the elderly effectively and

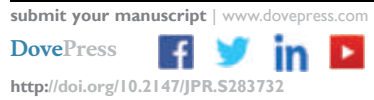


employ multidisciplinary intervention strategies to help address geriatric pain. Current studies on geriatric pain and its mechanisms could also improve the understanding of pain in the elderly and hence guide optimal treatment protocols. ${ }^{10-12}$ In short, research on pain in the elderly has attracted worldwide attention from scholars across the countries.

Bibliometrics, which refers to the application of mathematical and statistical methods to analyze scientific publications on a specific topic, ${ }^{13}$ serves to provide quantitative information on bibliographic properties, such as authors, journals, citation scores, and countries of distribution. ${ }^{14}$ Bibliometrics is an important tool to assess the impact or value in a specific field. ${ }^{15}$ Bibliometric analyses in the field of pain research usually involve a wide range of topics, ${ }^{16-21}$ such as specific disease-related pain. ${ }^{22,23}$ Only a limited number of bibliometric studies on the topic of pain among different age groups, especially in the elderly, have been conducted.

In view of the above-mentioned research gap, the purpose of the present study is to explore the scientific research trends in pain amongst the elderly as presented by related articles published between 2000 and 2019 in a systematic manner. This study used a bibliometric method similar to that employed by Mogil et $\mathrm{al}^{18}$ and Caes et al. ${ }^{24}$ The Web of Science (WoS) Core Collection was selected as the database to search and screen articles related to pain in the older population. CiteSpace V (Drexel University, Philadelphia, USA), ${ }^{25}$ which is frequently used for quantitative analysis, was adopted as an auxiliary tool. This visualization software is capable of producing node link maps and citation network maps, which allows an explicit manifestation of the development track, intellectual base, research hotspots, and other aspects of a discipline. ${ }^{26}$ CiteSpace $\mathrm{V}$ can also help detect keywords and references in citation bursts. Citation bursts are characterized by intensity and duration. The burst of citations indicates that attention to related research has increased over a period of time, which is a key indicator for identifying emerging trends. $^{27-29}$ This article mainly uses CiteSpace for references cluster analysis and citation bursts detection, and keywords citation bursts detection. Information on authors, journals, and country of distribution was also obtained.

\section{Methods}

\section{Source and Search Strategy}

WoS, particularly the core collection Science Citation Index (SCI) Expanded, was selected as the search database. The keywords for this study were referred from two previous meta-analyses ${ }^{30,31}$ and selected under the advice of a professor with extensive meta-analysis writing experience. We searched for all titles containing at least one word or phrase related to "elderly" and one word or phrase related to "pain". The keywords employed are provided in Supplement 1. We retained English articles only because of limitations in language mastery. Articles published in peer-reviewed journals from 2000 to 2019 were included for analysis in this study. We did not exclusively choose articles published in the journal PAIN because articles related to pain in the elderly may also be published in various medical-related journals. Besides original articles, we also considered reviews, theoretical articles and related guidelines. A total of 5096 articles were retrieved, and this step was completed on February 27, 2020.

\section{Preliminary Screening}

Two authors independently checked articles on the basis of their title to initially screen out duplicate papers and articles that met the exclusion criteria (eg, case studies, protocols, letters, books and articles that were unrelated to the topic of interest). Disagreements on inconsistent content were discussed and resolved. Articles that could not be judged as to whether they met the inclusion criteria based on their title were retained to the next step of screening. In this step, a total of 1691 (33.18\%) articles were excluded because of several reasons, such as other non-pain-related elderly studies $(\mathrm{N}=147,8.69 \%)$ or non-elderly studies $(\mathrm{N}=1046$, $61.86 \%$ ) due to the phrase being cut off or other reasons, articles identified in searches due to irrelevant words captured by truncated search terms or misspelled $(\mathrm{N}=374$, $22.12 \%)$, case studies $(\mathrm{N}=96,5.68 \%)$, duplicates $(\mathrm{N}=5$ or $0.30 \%)$ and protocol articles $(\mathrm{N}=23,1.36 \%)$. This screening step was completed on March 5, 2020.

\section{Access to Information}

The citation information of all articles was exported from WoS.

\section{Coding Strategy}

The coding system we used was developed by Mogil et a ${ }^{18}$ and modified it according to the version used in the research 
of Caes et $\mathrm{al}^{24}$ to meet the needs of the information acquired in this study. Information on the years the articles were published, content related to the authors (names and numbers), journals and citation scores were collected. We also collected information on the countries of the first authors. The information obtained from the titles and abstracts mainly included the following categories: (1) type of article (ie, research article, theoretical article, guidelines and reviews [ie, narrative reviews or systematic reviews]); (2) topic of the article (eg, characteristics, assessment, intervention, risk factors of pain); (3) subjects (eg, healthy cases, patients recruited from the community or clinical setting); and (4) pain characterisation (eg, experimental pain or clinical pain). Experimental pain includes pain induced by an electrical, mechanical, thermal, or other stimulus, while clinical pain includes pain caused by disease or surgery. Details of the coding system are provided in Supplement 2. We did not categorise the articles according to age because we found during the precoding process that many studies on pain in the elderly included a relatively wide age range. Thus, we used inclusion and exclusion criteria to limit the age range of the articles reviewed (Table 1).

On the basis of the coding system developed by Mogil et $\mathrm{al}^{18}$, each article was assigned at least one code in

Table I Inclusion and Exclusion Criteria

\begin{tabular}{|c|c|}
\hline Inclusion Criteria & Exclusion Criteria \\
\hline $\begin{array}{l}\checkmark \text { Articles from peer-reviewed } \\
\text { journals }\end{array}$ & $x$ Dissertation \\
\hline$\checkmark$ Research articles & $x$ Letters \\
\hline $\begin{array}{l}\checkmark \text { Reviews (ie, narrative review } \\
\text { and systematic review) }\end{array}$ & $x$ Conference abstracts \\
\hline$\checkmark$ Clinical guidelines & $x$ Case studies \\
\hline$\checkmark$ Theoretical articles & $x$ Protocols \\
\hline$\checkmark$ English articles & $x$ Books \\
\hline$\checkmark$ Abstract available & $x$ Non-elderly subjects \\
\hline $\begin{array}{l}\checkmark \text { Articles on pain in elderly } \\
\text { persons aged } \geq 65 \text { years old (at } \\
\text { least half of the main subjects) }\end{array}$ & $\begin{array}{l}x \text { Articles not related to pain or } \\
\text { whose main outcomes were } \\
\text { not pain }\end{array}$ \\
\hline $\begin{array}{l}\checkmark \text { Pain was the main outcome or } \\
\text { topic of interest }\end{array}$ & $\begin{array}{l}x \text { The symptoms of the disease } \\
\text { may include pain, but the study } \\
\text { did not focus on pain }\end{array}$ \\
\hline $\begin{array}{l}\checkmark \text { Articles about pain in the } \\
\text { elderly reported by medical } \\
\text { staff, caregivers, etc. }\end{array}$ & $\begin{array}{l}x \text { Article was retrieved because } \\
\text { of a misspelling or truncation }\end{array}$ \\
\hline
\end{tabular}

a category but allowed multiple codes because an article may match with multiple codes; For example, in terms of pain characteristics, chronic pain may be caused by a disease. Prior to formal coding, all of the authors involved in the coding process discussed and adjusted the relevant content of the coding system.

\section{Coding}

All abstracts obtained were equally distributed amongst four coders, who subsequently applied the coding system described above. In this step, a total of 1300 articles were excluded for the following reasons: (1) the article was not related to pain or did not specify pain as the main outcome $(\mathrm{N}=882,67.85 \%),(2)$ the article involved a non-elderly population ( $\mathrm{N}=299,23 \%)$, (3) the article did not include an abstract ( $\mathrm{N}=58,4.46 \%)$ or (4) the article was a case study $(\mathrm{N}=57$ or $4.38 \%)$. Finally, 2105 articles were included in the final step of analysis. The coding step was completed on March 31, 2020.

To ensure internal reliability, we randomly selected $10 \%$ of the articles assigned to each coder and asked the first author to code them. The range of the intraclass correlation coefficient obtained by statistics was $0.86-0.97$.

\section{Data Analysis}

The publication dates of the included articles were divided into periods of 4 years (ie, 2000-2003, 2004-2007, 2008-2011, 2012-2015, 2016-2019), each quantitative data were presented as a percentage. The time period was then considered an independent variable, and the categorical data were considered dependent variables. Linear regression was used to calculate changes in the percentage of categorical data over time. Because multiple codes are allowed for each category, the sum of all percentages in a category may exceed $100 \%$. Microsoft Excel 2016 and CiteSpace V were used for data collection and trend analysis, and IBM SPSS Statistics 22.0 software (SPSS Inc., Chicago, USA) was used for statistical analysis. P values less than 0.05 were considered to indicate statistically significant differences.

The complete data acquisition process is illustrated in Figure 1 .

\section{Results}

\section{Time Trend of Publication Outputs}

A total of 2105 articles were included for analysis. The number of publications increased from 25 articles in 2000 to 207 articles in 2019, and statistical analysis showed a significant correlation $\left(\mathrm{R}^{2}=0.936, \mathrm{P}<0.001\right)$ between 


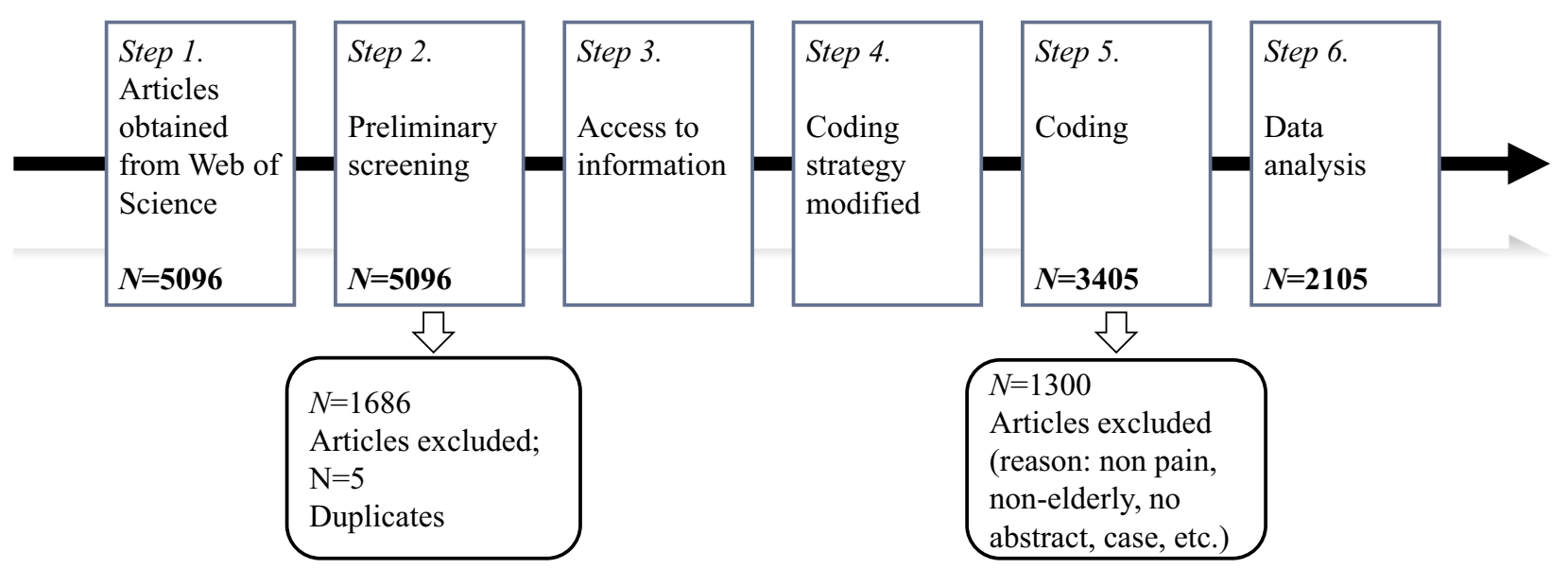

Figure I Flow chart for article selection.

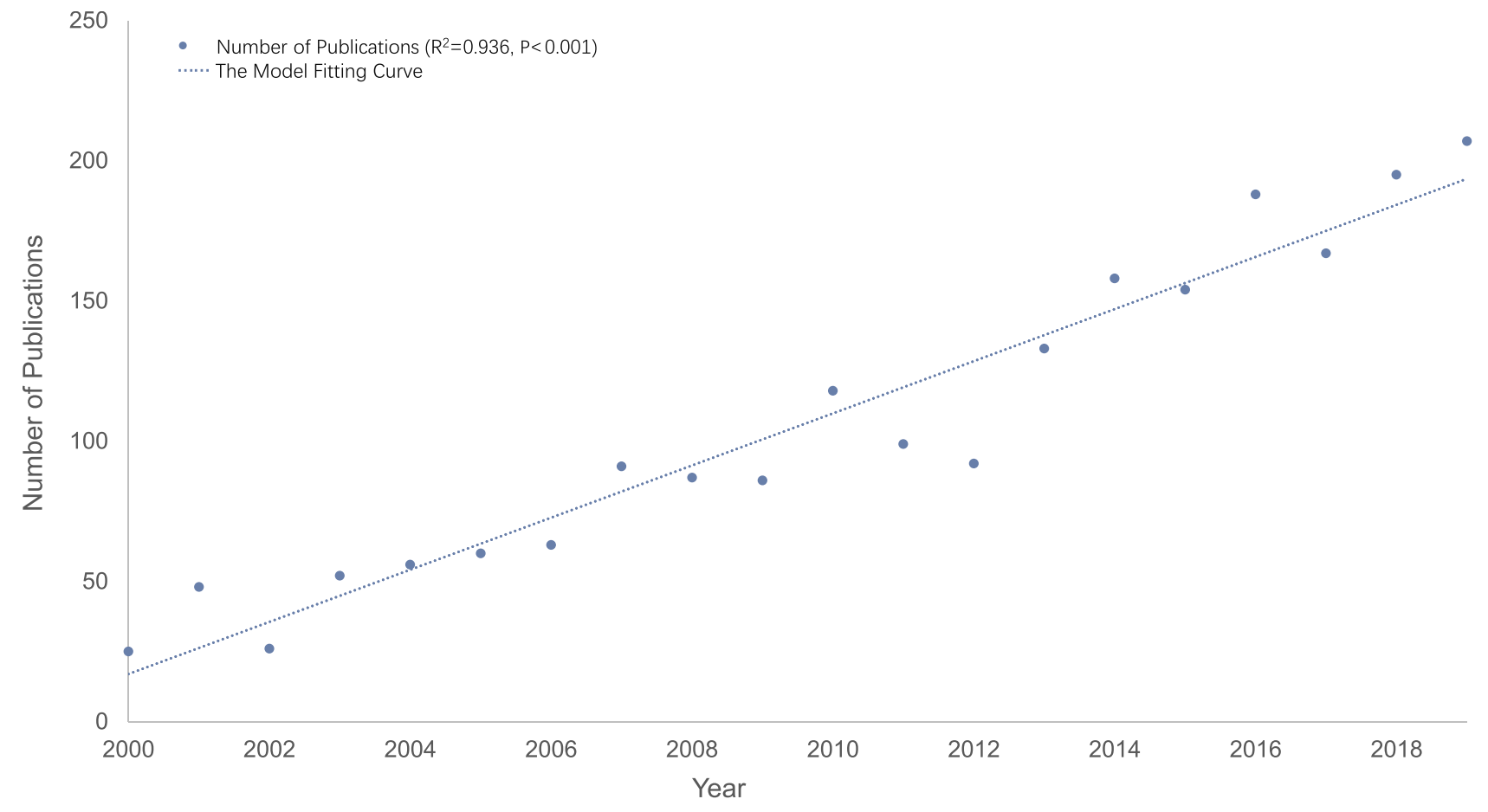

Figure 2 Number of articles published and the mode fitting curve from 2000 to 2019.

the year and number of publications. Details of the year distribution and time trends of the number of publications are shown in Figure 2.

\section{Number of Citations}

The top 20 articles with the highest total citation scores (ie, the total number of times cited) are shown in Table 2. The top 20 articles with the highest total citation scores focused on pain assessment (15\%), pain intervention (25\%), pain characteristics $(55 \%)$, and model development $(10 \%)$. The relative citation score is calculated as the total citation score divided by number of years after publication. Table 3 lists the top 20 articles with relative citation scores. In terms of the relative citation scores, the top 20 articles shared the similar research themes (ie, pain assessment: $20 \%$, pain intervention: $45 \%$, pain characteristics: $35 \%$ and model development: $5 \%$ ). 
Table 2 Top 20 Articles with the Highest Total Citation Scores

\begin{tabular}{|c|c|c|c|c|c|}
\hline Rank & Year & Authors & Title & Journal & $\begin{array}{l}\text { Citation } \\
\text { Score }\end{array}$ \\
\hline $\mathbf{I}$ & 2001 & Peat et al ${ }^{40}$ & $\begin{array}{l}\text { Knee pain and osteoarthritis in older adults: a review of } \\
\text { community burden and current use of primary health care }\end{array}$ & $\begin{array}{l}\text { Annals of the Rheumatic } \\
\text { Diseases }\end{array}$ & 725.00 \\
\hline 2 & 2004 & Messier et $\mathrm{al}^{41}$ & $\begin{array}{l}\text { Exercise and dietary weight loss in overweight and obese older } \\
\text { adults with knee osteoarthritis - The arthritis, diet, and activity } \\
\text { promotion trial }\end{array}$ & Arthritis and Rheumatism & 611.00 \\
\hline 3 & 2010 & Blagojevic et a ${ }^{42}$ & $\begin{array}{l}\text { Risk factors for onset of osteoarthritis of the knee in older } \\
\text { adults: a systematic review and meta-analysis }\end{array}$ & $\begin{array}{l}\text { Osteoarthritis and } \\
\text { Cartilage }\end{array}$ & 528.00 \\
\hline 4 & 2003 & Lin et $\mathrm{al}^{43}$ & $\begin{array}{l}\text { Effect of improving depression care on pain and functional } \\
\text { outcomes among older adults with arthritis - A randomized } \\
\text { controlled trial }\end{array}$ & JAMA & 375.00 \\
\hline 5 & 2007 & $\begin{array}{l}\text { Hadjistavropoulos } \\
\text { et } \mathrm{al}^{44}\end{array}$ & $\begin{array}{l}\text { An interdisciplinary expert consensus statement on assessment } \\
\text { of pain in older persons }\end{array}$ & Clinical Journal of Pain & 331.00 \\
\hline 6 & 2004 & Thomas et $\mathrm{al}^{45}$ & $\begin{array}{l}\text { The prevalence of pain and pain interference in a general } \\
\text { population of older adults: cross-sectional findings from the } \\
\text { North Staffordshire Osteoarthritis Project (NorStOP) }\end{array}$ & PAIN & 314.00 \\
\hline 7 & 2013 & Abdulla et $\mathrm{al}^{45}$ & Guidance on the management of pain in older people & Age and Ageing & 300.00 \\
\hline 8 & 2004 & Herr et $\mathrm{al}^{46}$ & $\begin{array}{l}\text { Pain intensity assessment in older adults - Use of experimental } \\
\text { pain to compare psychometric properties and usability of } \\
\text { selected pain scales with younger adults }\end{array}$ & Clinical Journal of Pain & 267.00 \\
\hline 9 & 2001 & $\begin{array}{l}\text { Helme and } \\
\text { Gibson. }{ }^{47}\end{array}$ & The epidemiology of pain in elderly people & $\begin{array}{l}\text { Clinics in Geriatric } \\
\text { Medicine }\end{array}$ & 255.00 \\
\hline 10 & 2006 & Herr et $\mathrm{al}^{48}$ & $\begin{array}{l}\text { Tools for assessment of pain in nonverbal older adults with } \\
\text { dementia: A state-of-the-science review }\end{array}$ & $\begin{array}{l}\text { Journal of Pain and } \\
\text { Symptom Management }\end{array}$ & 254.00 \\
\hline II & 2008 & Morone et $\mathrm{al}^{49}$ & $\begin{array}{l}\text { Mindfulness meditation for the treatment of chronic low back } \\
\text { pain in older adults: A randomized controlled pilot study }\end{array}$ & PAIN & 249.00 \\
\hline 12 & 2001 & Jones et $\mathrm{a}^{50}$ & $\begin{array}{l}\text { The effect of age on pain, function, and quality of life after total } \\
\text { hip and knee arthroplasty }\end{array}$ & $\begin{array}{l}\text { Archives of Internal } \\
\text { Medicine }\end{array}$ & 236.00 \\
\hline 13 & 2010 & Solomon et $\mathrm{al}^{51}$ & $\begin{array}{l}\text { The comparative safety of analgesics in older adults with } \\
\text { arthritis }\end{array}$ & $\begin{array}{l}\text { Archives of Internal } \\
\text { Medicine }\end{array}$ & 236.00 \\
\hline 14 & 2001 & $\begin{array}{l}\text { Gibson and } \\
\text { Helme }^{52}\end{array}$ & Age-related differences in pain perception and report & $\begin{array}{l}\text { Clinics in Geriatric } \\
\text { Medicine }\end{array}$ & 235.00 \\
\hline 15 & 2009 & Leveille et $\mathrm{al}^{53}$ & $\begin{array}{l}\text { Chronic musculoskeletal pain and the occurrence of falls in an } \\
\text { older population }\end{array}$ & JAMA & 228.00 \\
\hline 16 & 2005 & Gagliese et $\mathrm{a}^{54}$ & $\begin{array}{l}\text { The measurement of postoperative pain: A comparison of } \\
\text { intensity scales in younger and older surgical patients }\end{array}$ & PAIN & 226.00 \\
\hline 17 & 2004 & $\begin{array}{l}\text { Gibson and } \\
\text { Farrell }^{55}\end{array}$ & $\begin{array}{l}\text { A review of age differences in the neurophysiology of } \\
\text { nociception and the perceptual experience of pain }\end{array}$ & Clinical Journal of Pain & 212.00 \\
\hline 18 & 2005 & $\begin{array}{l}\text { Lautenbacher } \\
\text { et } \mathrm{al}^{56}\end{array}$ & $\begin{array}{l}\text { Age effects on pain thresholds, temporal summation and spatial } \\
\text { summation of heat and pressure pain }\end{array}$ & PAIN & 211.00 \\
\hline
\end{tabular}


Table 2 (Continued).

\begin{tabular}{|l|l|l|l|l|c|}
\hline Rank & Year & Authors & Title & Journal & $\begin{array}{l}\text { Citation } \\
\text { Score }\end{array}$ \\
\hline 19 & 2015 & Silverwood et al & & $\begin{array}{l}\text { Current evidence on risk factors for knee osteoarthritis in } \\
\text { older adults: a systematic review and meta-analysis }\end{array}$ & $\begin{array}{l}\text { Osteoarthritis and } \\
\text { Cartilage }\end{array}$ \\
\hline 20 & 2003 & Edwards et al & $\begin{array}{l}\text { Age-related differences in endogenous pain modulation: } \\
\text { a comparison of diffuse noxious inhibitory controls in healthy } \\
\text { older and younger adults }\end{array}$ & PAIN & 209.00 \\
\hline
\end{tabular}

Table 3 Top 20 Articles with the Highest Relative Citation Scores

\begin{tabular}{|c|c|c|c|c|c|}
\hline Rank & Year & Author & Title & Journal & $\begin{array}{l}\text { Relative } \\
\text { Citation } \\
\text { Scores }\end{array}$ \\
\hline $\mathbf{I}$ & 2010 & Blagojevic et al ${ }^{42}$ & $\begin{array}{l}\text { Risk factors for onset of osteoarthritis of the knee in older adults: } \\
\text { a systematic review and meta-analysis }\end{array}$ & $\begin{array}{l}\text { Osteoarthritis and } \\
\text { Cartilage }\end{array}$ & 52.80 \\
\hline 2 & 2013 & Abdulla et $\mathrm{al}^{6}$ & Guidance on the management of pain in older people & Age and Ageing & 42.86 \\
\hline 3 & 2015 & Silverwood et $\mathrm{al}^{57}$ & $\begin{array}{l}\text { Current evidence on risk factors for knee osteoarthritis in older } \\
\text { adults: a systematic review and meta-analysis }\end{array}$ & $\begin{array}{l}\text { Osteoarthritis and } \\
\text { Cartilage }\end{array}$ & 42.20 \\
\hline 4 & 2004 & Messier et $\mathrm{al}^{4 !}$ & $\begin{array}{l}\text { Exercise and dietary weight loss in overweight and obese older adults } \\
\text { with knee osteoarthritis - The arthritis, diet, and activity promotion } \\
\text { trial }\end{array}$ & $\begin{array}{l}\text { Arthritis and } \\
\text { Rheumatism }\end{array}$ & 38.19 \\
\hline 5 & 2001 & Peat et $\mathrm{al}^{40}$ & $\begin{array}{l}\text { Knee pain and osteoarthritis in older adults: a review of community } \\
\text { burden and current use of primary health care }\end{array}$ & $\begin{array}{l}\text { Annals of the } \\
\text { Rheumatic } \\
\text { Diseases }\end{array}$ & 38.16 \\
\hline 6 & 2013 & Patel et $\mathrm{al}^{58}$ & $\begin{array}{l}\text { Prevalence and impact of pain among older adults in the United States: } \\
\text { Findings from the } 201 \mathrm{I} \text { National Health and Aging Trends Study }\end{array}$ & PAIN & 29.57 \\
\hline 7 & 2007 & $\begin{array}{l}\text { Hadjistavropoulos } \\
\text { et } \mathrm{al}^{44}\end{array}$ & $\begin{array}{l}\text { An interdisciplinary expert consensus statement on assessment of } \\
\text { pain in older persons }\end{array}$ & $\begin{array}{l}\text { Clinical Journal of } \\
\text { Pain }\end{array}$ & 25.46 \\
\hline 8 & 2010 & Solomon et $\mathrm{al}^{51}$ & The comparative safety of analgesics in older adults with arthritis & $\begin{array}{l}\text { Archives of } \\
\text { Internal Medicine }\end{array}$ & 23.60 \\
\hline 9 & 2017 & Avidan et $\mathrm{al}^{59}$ & $\begin{array}{l}\text { Intraoperative ketamine for prevention of postoperative delirium or } \\
\text { pain after major surgery in older adults: an international, multicentre, } \\
\text { double-blind, randomised clinical trial }\end{array}$ & Lancet & 23.33 \\
\hline 10 & 2003 & Lin et $\mathrm{al}^{43}$ & $\begin{array}{l}\text { Effect of improving depression care on pain and functional outcomes } \\
\text { among older adults with arthritis - A randomized controlled trial }\end{array}$ & JAMA & 22.06 \\
\hline II & 2008 & Morone et $\mathrm{al}^{49}$ & $\begin{array}{l}\text { Mindfulness meditation for the treatment of chronic low back pain in } \\
\text { older adults: A randomized controlled pilot study }\end{array}$ & PAIN & 20.75 \\
\hline 12 & 2009 & Leveille et $\mathrm{a}^{53}$ & $\begin{array}{l}\text { Chronic musculoskeletal pain and the occurrence of falls in an older } \\
\text { population }\end{array}$ & JAMA & 20.73 \\
\hline 13 & 2004 & Thomas et $\mathrm{a}^{45}$ & $\begin{array}{l}\text { The prevalence of pain and pain interference in a general population } \\
\text { of older adults: cross-sectional findings from the North Staffordshire } \\
\text { Osteoarthritis Project (NorStOP) }\end{array}$ & PAIN & 19.63 \\
\hline
\end{tabular}


Table 3 (Continued).

\begin{tabular}{|c|c|c|c|c|c|}
\hline Rank & Year & Author & Title & Journal & $\begin{array}{l}\text { Relative } \\
\text { Citation } \\
\text { Scores }\end{array}$ \\
\hline 14 & 2006 & Herr et $\mathrm{al}^{48}$ & $\begin{array}{l}\text { Tools for assessment of pain in nonverbal older adults with dementia: } \\
\text { A state-of-the-science review }\end{array}$ & $\begin{array}{l}\text { Journal of Pain and } \\
\text { Symptom } \\
\text { Management }\end{array}$ & 18.14 \\
\hline 15 & 2004 & Herr et $\mathrm{al}^{46}$ & $\begin{array}{l}\text { Pain intensity assessment in older adults - Use of experimental pain to } \\
\text { compare psychometric properties and usability of selected pain scales } \\
\text { with younger adults }\end{array}$ & $\begin{array}{l}\text { Clinical Journal of } \\
\text { Pain }\end{array}$ & 16.69 \\
\hline 16 & 2013 & Langan et $\mathrm{al}^{61}$ & $\begin{array}{l}\text { Herpes zoster vaccine effectiveness against incident herpes zoster and } \\
\text { post-herpetic neuralgia in an older US population: A cohort study }\end{array}$ & PLoS Medicine & 16.43 \\
\hline 17 & 2016 & Morone et $\mathrm{al}^{62}$ & $\begin{array}{l}\text { A mind-body program for older adults with chronic low back pain } \\
\text { a randomized clinical trial }\end{array}$ & $\begin{array}{l}\text { JAMA Internal } \\
\text { Medicine }\end{array}$ & 16.25 \\
\hline 18 & 2009 & Vitiello et $\mathrm{al}^{63}$ & $\begin{array}{l}\text { Cognitive behavioral therapy for insomnia improves sleep and } \\
\text { decreases pain in older adults with co-morbid insomnia and } \\
\text { osteoarthritis }\end{array}$ & $\begin{array}{l}\text { Journal of Clinical } \\
\text { Sleep Medicine }\end{array}$ & 16.09 \\
\hline 19 & 2014 & $\begin{array}{l}\text { Hadjistavropoulos } \\
\text { et } \mathrm{al}^{32}\end{array}$ & Pain assessment in elderly adults with dementia & Lancet Neurology & 15.83 \\
\hline 20 & 2014 & Makris et $\mathrm{al}^{33}$ & Management of persistent pain in the older patient a clinical review & JAMA & 15.67 \\
\hline
\end{tabular}

\section{Journals}

All included articles were published in 535 journals, and 261 journals published two or more of these articles. The top three journals with the greatest number of publications related to pain in the elderly were Pain Medicine, PAIN, and Journal of the American Geriatrics Society. Details of the top 20 journals with the highest number of pain-related articles published are shown in Table 4. The average impact factor (IF) of all journals was 3.053 (median, 2.930; range, 1.595-5.483, 2019), and the total number of citations of PAIN reached 4337 (publications, 78; IF, $2019=5.483$; citations per paper, 55.60), which was the journal with the largest total number of citations and the journal with the most citations per article. In addition, over half of the top 20 journals that published articles on pain were from the United States.

\section{Authors}

The percentage of articles in which two or more authors collaborate gradually increased over time. Author collaborations increased from $91.39 \%$ in $2000-2003$ to $97.90 \%$ in 2016-2019 $\left(\mathrm{R}^{2}=0.886, \mathrm{P}<0.05\right)$. Conversely, the proportion of articles published by a single author declined over this same period $\left(\mathrm{R}^{2}=0.882, \mathrm{P}<0.05\right)$. Details of our analysis on authors are provided in Figure 3. No articles in which the authors were anonymous or not listed were obtained.

The articles included in this analysis were published in 48 countries (Supplement 3), but most came from the United States $(\mathrm{N}=741,35.20 \%)$, Australia $(\mathrm{N}=175$, $8.31 \%)$ and the United Kingdom ( $\mathrm{N}=167,7.93 \%)$. The distribution of articles published per country is shown in Figure 4.

\section{Keywords}

CiteSpace was used to detect burst keywords which were identified as indicators of emerging trends. The burstiness of a keyword was obtained by calculating the weighted sum of its frequency in one- or multiple-time windows. If the probability of these occurrences is higher than a datadependent global threshold, that keyword is considered to have a burst. All keywords of the included papers were obtained by CiteSpace V. The top 68 keywords with the strongest citation bursts are shown in Table 5. The burst keywords in the beginning of 2000 were "migraine", 'osteoarthritis', "rheumatoid", "gender", "nursing home" and "physical disability". By comparison, the most recent burst keywords included "balance" (2014-2019), "burden" 
Table 4 Top 20 Journals with the Highest Number of Published Articles

\begin{tabular}{|c|c|c|c|c|c|c|}
\hline Rank & Journal & Country & IF (20|9) & Count & Citation Scores & Citations per Paper \\
\hline $\mathbf{I}$ & Pain Medicine & USA & 2.513 & 105 & 2477 & 23.59 \\
\hline 2 & PAIN & USA & 5.483 & 78 & 4337 & 55.60 \\
\hline 3 & Journal of the American Geriatrics Society & USA & 4.180 & 70 & 3099 & 44.27 \\
\hline 4 & Pain Management Nursing & USA & 1.595 & 50 & 670 & 13.40 \\
\hline 5 & Drugs \& Aging & New Zealand & 2.824 & 48 & 1016 & 21.17 \\
\hline 6 & European Journal of Pain & England & 3.492 & 39 & 729 & 18.69 \\
\hline 7 & Journal of Pain & USA & 4.621 & 38 & $|53|$ & 40.29 \\
\hline 8 & Clinical Journal of Pain & USA & 2.893 & 38 & 1803 & 44.45 \\
\hline 9 & Clinics in Geriatric Medicine & USA & 2.966 & 32 & 1064 & 33.25 \\
\hline 10 & Bmc Geriatrics & England & 3.077 & 31 & 232 & 7.48 \\
\hline II & Bmc Musculoskeletal Disorders & England & 1.879 & 30 & 648 & 21.60 \\
\hline 12 & Archives of Gerontology and Geriatrics & Ireland & 2.128 & 30 & 314 & 10.47 \\
\hline 13 & $\begin{array}{l}\text { Journals of Gerontology Series a-Biological } \\
\text { Sciences and Medical Sciences }\end{array}$ & USA & 5.236 & 27 & 700 & 25.93 \\
\hline 14 & Journal of Pain and Symptom Management & USA & 3.077 & 26 & 969 & 37.27 \\
\hline 15 & SPINE & USA & 2.646 & 24 & 716 & 29.83 \\
\hline 16 & Aging Clinical and Experimental Research & Italy & 2.697 & 24 & 154 & 6.42 \\
\hline 17 & Journal of Clinical Nursing & England & 1.972 & 23 & 345 & 15.00 \\
\hline 18 & Clinical Interventions in Aging & New Zealand & 3.023 & 22 & 268 & 12.18 \\
\hline 19 & PLoS One & USA & 2.740 & 20 & 160 & 8.00 \\
\hline 20 & Geriatrics \& Gerontology International & Japan & 2.022 & 20 & 103 & 5.15 \\
\hline
\end{tabular}

(2015-2019), “cognitive impairment" (2015-2019), 'metaanalysis' (2015-2019), "impact” (2016-2019), "mortality" (2016-2019), “predictor" (2017-2019) and "persistent pain" (2017-2019).

\section{Subject Category in Web of Science}

All articles included in the analysis were divided into 52 categories in WoS. Most of the published articles described topics related to Geriatrics \& Gerontology $(\mathrm{N}=508)$, followed by Neurosciences \& Neurology $(\mathrm{N}=464)$ and Clinical Neurology $(\mathrm{N}=406)$. The top 10 subject categories with the strongest citation bursts in the last 20 years are shown in Table 6. Whilst the subject category with the strongest citation bursts at the beginning of 2000 was Neurosciences (2000-2005), the top 10 subject categories with the strongest citation bursts by the end of 2019 included Multidisciplinary Sciences (2015-2019) and Science \& TechnologyOther Topics (2015-2019).

\section{References}

Reference analysis is an essential aspect of bibliometric research in a specific field. CiteSpace V was used to obtain citation data from the included articles, and the top 19 clusters are displayed in a timeline view in Figure 5; the scientific relevance of the included articles is also shown in the map. "Hip fracture" formed the largest cluster \#0, "elderly patient" formed the second largest cluster \#1, and "community-based" (\#2) and "functional self-efficacy" (\#3) respectively formed the third and fourth largest clusters. 


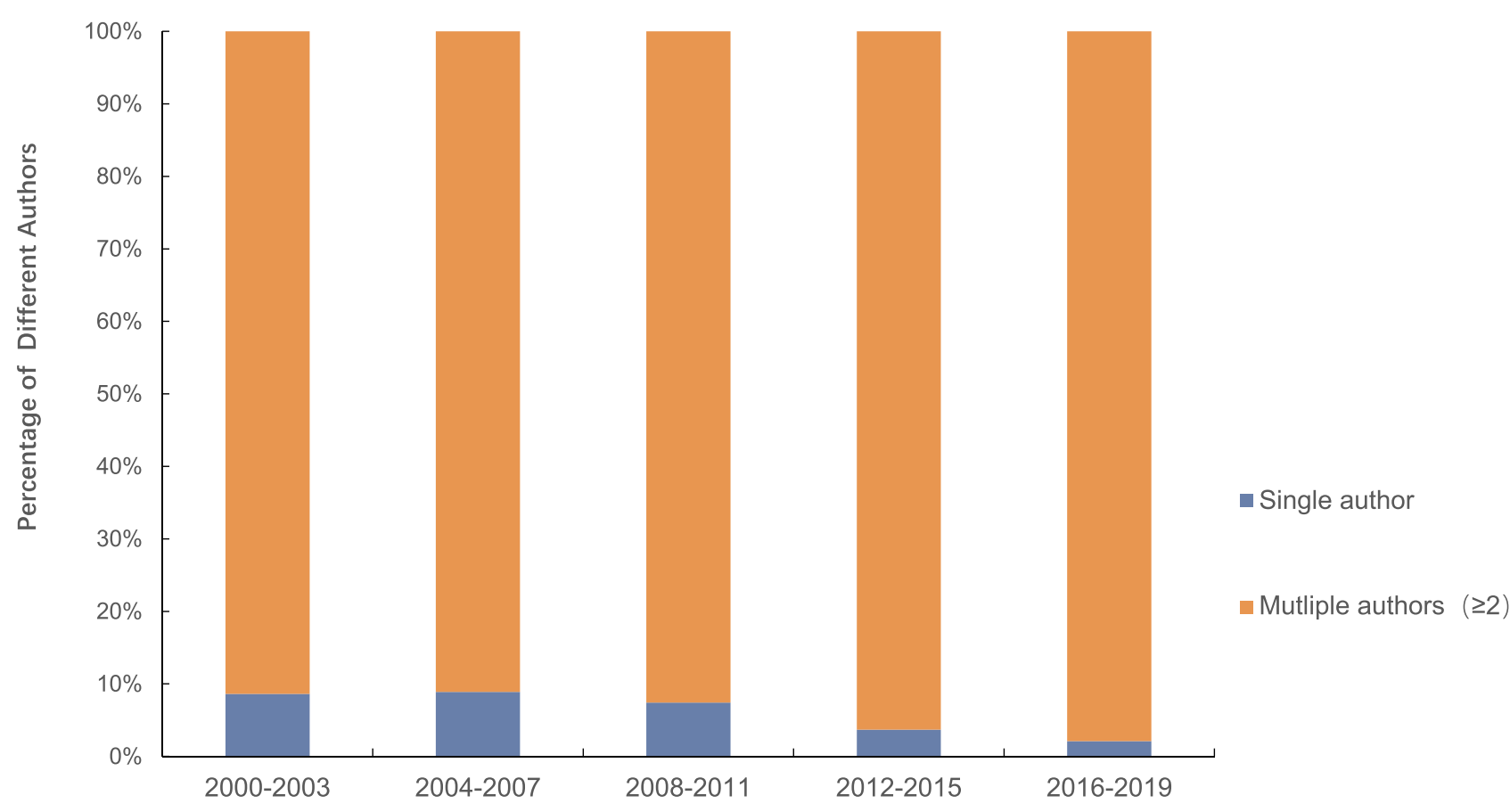

Figure 3 Percentage of papers published by single and multiple authors.

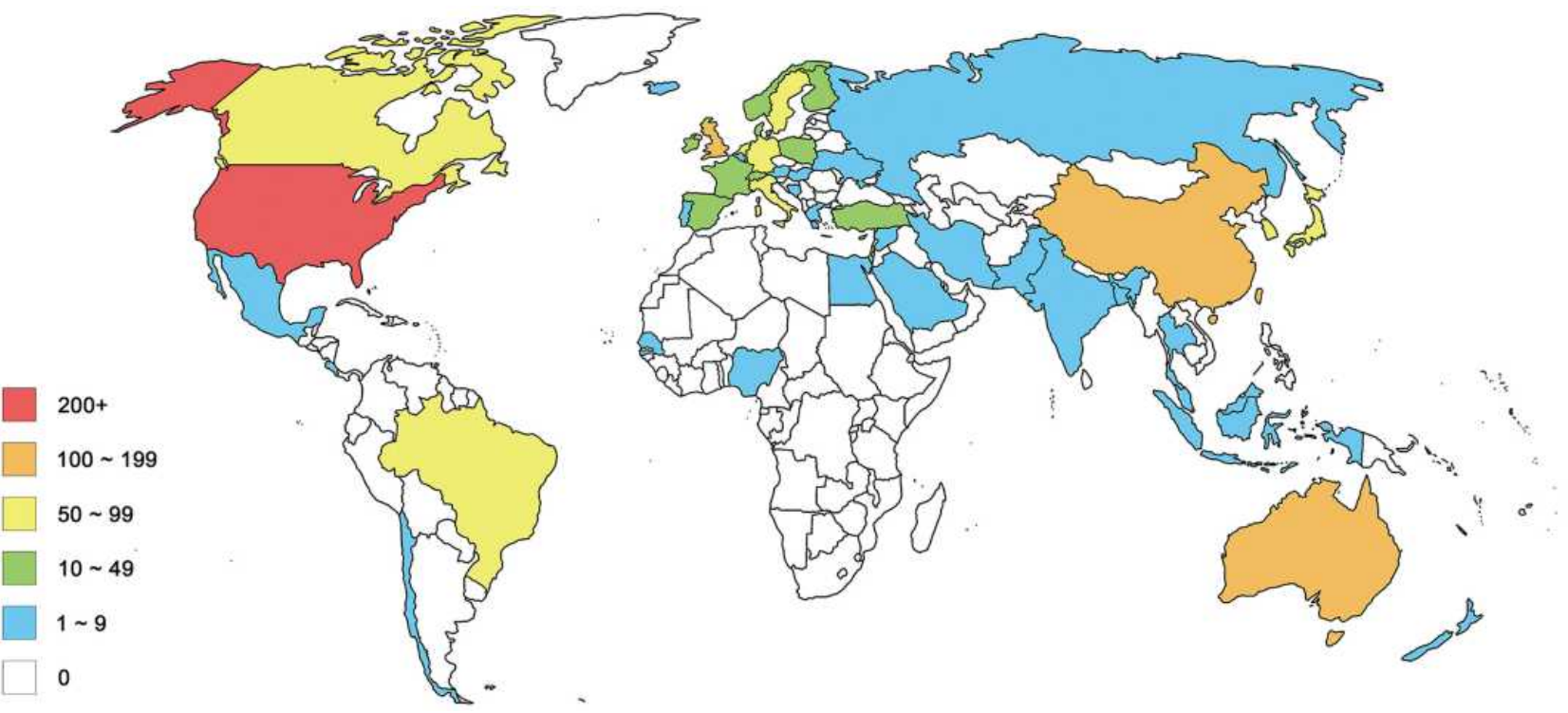

Figure 4 World map of total country outputs.

\section{Type of Article}

Original research articles were the dominant article type published and consistently made up $80.37-88.38 \%$ of the total number of articles published in each time period. By comparison, review articles made up $11.26-16.67 \%$ of the published articles. The percentage of theoretical articles and guidelines was relatively small (Figure 6A). Narrative reviews ( $\mathrm{N}=197,74.06 \%)$ accounted for the largest proportion of all review articles. Whilst the proportion of systematic reviews was initially low, this article type showed an upward trend over time $\left(\mathrm{R}^{2}=0.729, \mathrm{P}=0.065\right)$.

\section{Topic of Article}

Figure 6B shows the distribution of all included articles by topic (refer to Supplement 4 for detailed coding rules of topics). Articles on pain characteristics 
Table 5 Top 68 Keywords with the Strongest Citation Bursts in Publications on Pain in the Elderly

\begin{tabular}{|c|c|c|c|c|c|}
\hline Keywords & Year & Strength & Begin & End & 2000-2019 \\
\hline Migraine & 2000 & 4.2682 & 2000 & 2008 & י1 \\
\hline Osteo arthritis & 2000 & 7.9365 & 2000 & 2001 & 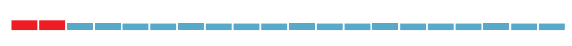 \\
\hline Rheumatoid arthritis & 2000 & 14.2934 & 2000 & 2011 & 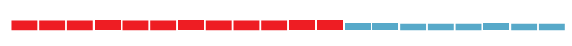 \\
\hline Gender & 2000 & 3.8488 & 2000 & 2005 & 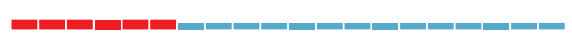 \\
\hline Nursing home & 2000 & 10.8974 & 2000 & 2005 & . \\
\hline Physical disability & 2000 & 4.2917 & 2000 & 2003 & \\
\hline Severity & 2000 & 4.0377 & 2002 & 2005 & -ーா \\
\hline Pain assessment & 2000 & 4.3778 & 2002 & 2006 & \\
\hline Mini mental state & 2000 & 4.5985 & 2002 & 2008 & 1- \\
\hline Mobility & 2000 & 5.3971 & 2003 & 2011 & 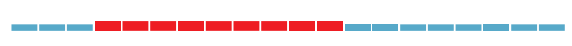 \\
\hline Geriatrics & 2000 & 4.2576 & 2003 & 2006 & - \\
\hline Validity & 2000 & 3.8645 & 2003 & 2007 & 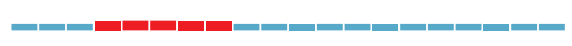 \\
\hline Questionnaire & 2000 & 7.0498 & 2003 & 2005 & 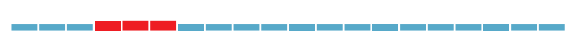 \\
\hline Headache & 2000 & 3.4825 & 2003 & 2004 & -1-1 \\
\hline Health status & 2000 & 5.2123 & 2003 & 2008 & \\
\hline Depressive symptom & 2000 & 6.7369 & 2003 & 2007 & 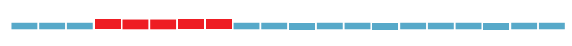 \\
\hline Elderly people & 2000 & 6.1618 & 2003 & 2008 & 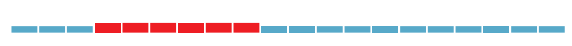 \\
\hline Surgery & 2000 & 3.5827 & 2003 & 2010 & 1 \\
\hline Attitude & 2000 & 3.5439 & 2003 & 2005 & \\
\hline Postoperative pain & 2000 & 5.1525 & 2003 & 2009 & \\
\hline Communication & 2000 & 3.7038 & 2004 & 2009 & 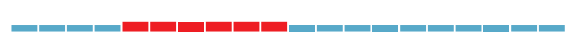 \\
\hline Disease & 2000 & 3.5381 & 2004 & 2008 & \\
\hline Arthroplasty & 2000 & 4.1529 & 2004 & 2006 & - \\
\hline Assessment & 2000 & 4.1674 & 2004 & 2009 & \\
\hline Experience & 2000 & 3.2414 & 2005 & 2011 & \\
\hline Minimum data set & 2000 & 3.1373 & 2005 & 2006 & 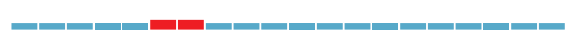 \\
\hline Nursing home resident & 2000 & 5.7317 & 2006 & 2008 & 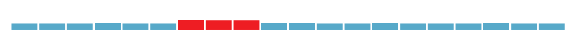 \\
\hline Intensity & 2000 & 5.7697 & 2006 & 2008 & - \\
\hline Follow up & 2000 & 3.7993 & 2007 & 2011 & \\
\hline Validation & 2000 & 7.6445 & 2007 & 2012 & \\
\hline Morphine & 2000 & 5.7343 & 2008 & 2010 & 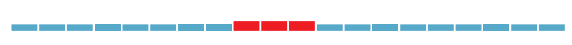 \\
\hline Patient & 2000 & 3.3089 & 2008 & 2013 & \\
\hline Disorder & 2000 & 6.8295 & 2008 & 2011 & \\
\hline
\end{tabular}


Table 5 (Continued).

\begin{tabular}{|c|c|c|c|c|c|}
\hline Keywords & Year & Strength & Begin & End & 2000-2019 \\
\hline Knee pain & 2000 & 3.1164 & 2008 & 2009 & 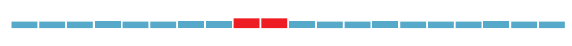 \\
\hline General population & 2000 & 3.2829 & 2008 & 2009 & 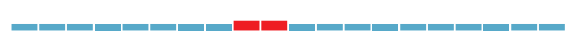 \\
\hline Nurse & 2000 & 3.6281 & 2009 & 2011 & 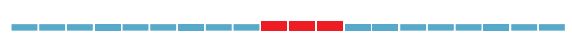 \\
\hline Cancer & 2000 & 5.4605 & 2009 & 2013 & \\
\hline Barrier & 2000 & 3.6625 & 2009 & 2013 & 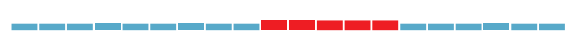 \\
\hline Alzheimer's disease & 2000 & 5.5734 & 2010 & 2012 & 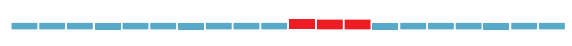 \\
\hline Guideline & 2000 & 5.5734 & 2010 & 2012 & 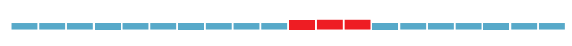 \\
\hline Knee & 2000 & 4.4126 & 2010 & 2013 & 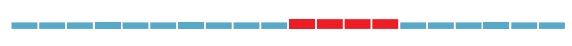 \\
\hline Fibromyalgia & 2000 & 5.0512 & 2010 & 2011 & 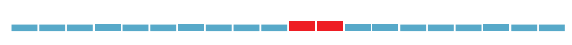 \\
\hline Diagnosis & 2000 & 3.1101 & 2011 & 2013 & 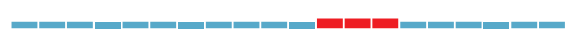 \\
\hline Nonsteroidal anti-inflammatory drug & 2000 & 3.1223 & 2011 & 2014 & \\
\hline Pain management & 2000 & 4.176 & 2012 & 2013 & 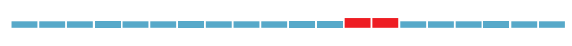 \\
\hline Efficacy & 2000 & 5.8437 & 2012 & 2015 & - \\
\hline Analgesia & 2000 & 3.6708 & 2012 & 2013 & \\
\hline Cancer pain & 2000 & 3.3727 & 2012 & 2013 & - \\
\hline Program & 2000 & 3.8164 & 2012 & 2014 & 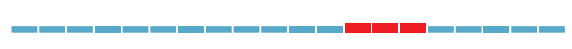 \\
\hline Safety & 2000 & 4.0307 & 2012 & 2015 & 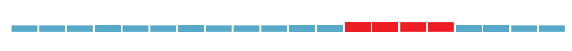 \\
\hline Outcome & 2000 & 9.3702 & 2013 & 2016 & 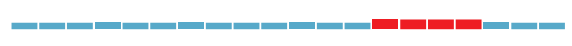 \\
\hline Anxiety & 2000 & 4.8392 & 2013 & 2016 & 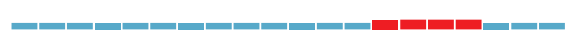 \\
\hline Elderly patient & 2000 & 5.3176 & 2013 & 2014 & 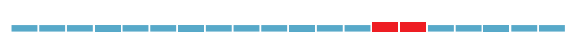 \\
\hline Double blind & 2000 & 3.3266 & 2013 & 2015 & 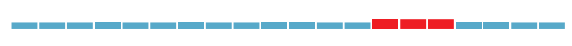 \\
\hline Neuropathic pain & 2000 & 3.6078 & 2014 & 2015 & 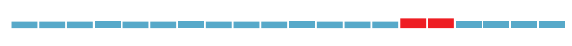 \\
\hline Perception & 2000 & 3.389 & 2014 & 2015 & ש-1- \\
\hline Balance & 2000 & 3.5721 & 2014 & 2019 & مس \\
\hline Performance & 2000 & 3.167 & 2014 & 2015 & 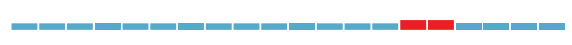 \\
\hline Burden & 2000 & 6.4995 & 2015 & 2019 & שח \\
\hline Cognitive impairment & 2000 & 3.3577 & 2015 & 2019 & 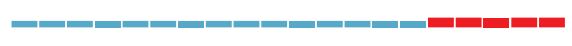 \\
\hline Cohort & 2000 & 5.8722 & 2015 & 2017 & 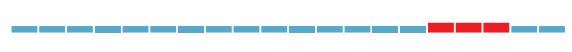 \\
\hline Clinical trial & 2000 & 3.4816 & 2015 & 2017 & 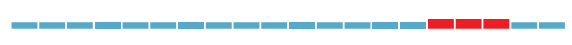 \\
\hline Meta-analysis & 2000 & 12.6695 & 2015 & 2019 & 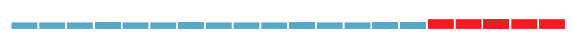 \\
\hline Impact & 2000 & 3.5607 & 2016 & 2019 & 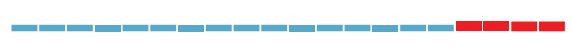 \\
\hline Physical function & 2000 & 4.5148 & 2016 & 2017 & 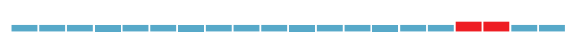 \\
\hline Mortality & 2000 & 7.3694 & 2016 & 2019 & שصسع-1-1 \\
\hline
\end{tabular}


Table 5 (Continued).

\begin{tabular}{|l|l|l|l|l|l|}
\hline Keywords & Year & Strength & Begin & End & $\mathbf{2 0 0 0 - 2 0 1 9}$ \\
\hline Predictor & 2000 & 5.339 & 2017 & 2019 & \\
\hline Persistent pain & 2000 & 7.4243 & 2017 & 2019 & - \\
\hline
\end{tabular}

Table 6 Top 10 Subject Categories of Articles on Pain in the Elderly with the Strongest Citation Bursts in Web of Science

\begin{tabular}{|c|c|c|c|c|c|}
\hline Subject Categories & Year & Strength & Begin & End & $2000-2019$ \\
\hline Neurosciences & 2000 & 5.0467 & 2000 & 2005 & 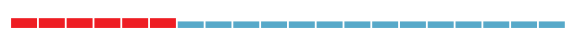 \\
\hline Gerontology & 2000 & 3.285 & 2004 & 2005 & - \\
\hline Rheumatology & 2000 & 3.2323 & 2004 & 2007 & יடாடா \\
\hline Anesthesiology & 2000 & 3.1168 & 2007 & 2008 & 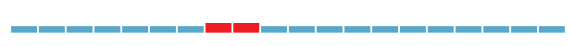 \\
\hline Oncology & 2000 & 6.4401 & 2008 & 2010 & 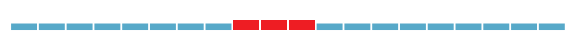 \\
\hline Pharmacology \& Pharmacy & 2000 & 4.058 & 2012 & 2014 & 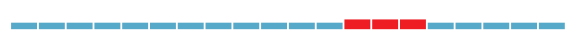 \\
\hline Health Policy \& Services & 2000 & 3.646 & 2013 & 2014 & - \\
\hline Obstetrics \& Gynecology & 2000 & 3.6245 & 2014 & 2016 & - \\
\hline Multidisciplinary Sciences & 2000 & 3.9403 & 2015 & 2019 & عسصس \\
\hline Science \& Technology - Other Topics & 2000 & 3.9403 & 2015 & 2019 & سعسعس \\
\hline
\end{tabular}

(42.56-53.90\%), pain intervention (30.74-39.23\%) and pain assessment (7.53-13.85\%) accounted for the largest proportion of all articles published from 2000 to 2019 . All topic categories showed a relatively stable distribution percentage over time (all $\mathrm{R}^{2}<0.638$, n.s.).

\section{Subject Type}

Approximately $49 \%$ of all articles did not mention the source of their subjects. Other articles recruited subjects from the clinical (23.82\%) and community (18.95\%) settings. Healthy subjects (3.17\%), nursing home residents $(3.07 \%)$, health professionals $(2.22 \%)$, and animals accounted for a small proportion of the subjects described in the articles (Figure 7). All studies subjects did not reveal significant changes over time. We found that, besides traditional clinical samples, a large proportion of the subjects came from the community. Studies in which subjects were recruited from the community were published in 31 countries. Figure 8 shows the proportion of published research involving communitybased subjects relative to the total number of studies published in each country. Nigeria, Bosnia-Herzegovina and Bangladesh published only one article each including community-based subjects. The countries with the highest percentages of published studies involving communitybased subjects were Finland (50\%), Thailand (44.44\%) and Japan (34.02\%).

\section{Pain Characteristics}

Studies on disease-related pain in the elderly were highly popular at all period studied and showed an increasing trend over time $\left(\mathrm{R}^{2}=0.973, \mathrm{P}<0.01\right)$. These studies made up $47.02 \%$ of all studies published in 2000-2003 and $57.46 \%$ of all studies published in 2016-2019. The types of pain with the largest number of publications were back pain $(\mathrm{N}=259,12.30 \%)$, arthritis $(\mathrm{N}=241,11.45 \%)$ and postsurgical pain $(\mathrm{N}=98,4.66 \%)$. Moreover, in all periods studied, the proportion of studies related to chronic pain was higher than the proportion of studies related to acute pain (Figure 9A). Studies on elderly surgery-related pain showed fair stability over time and varied between $4.47 \%$ 


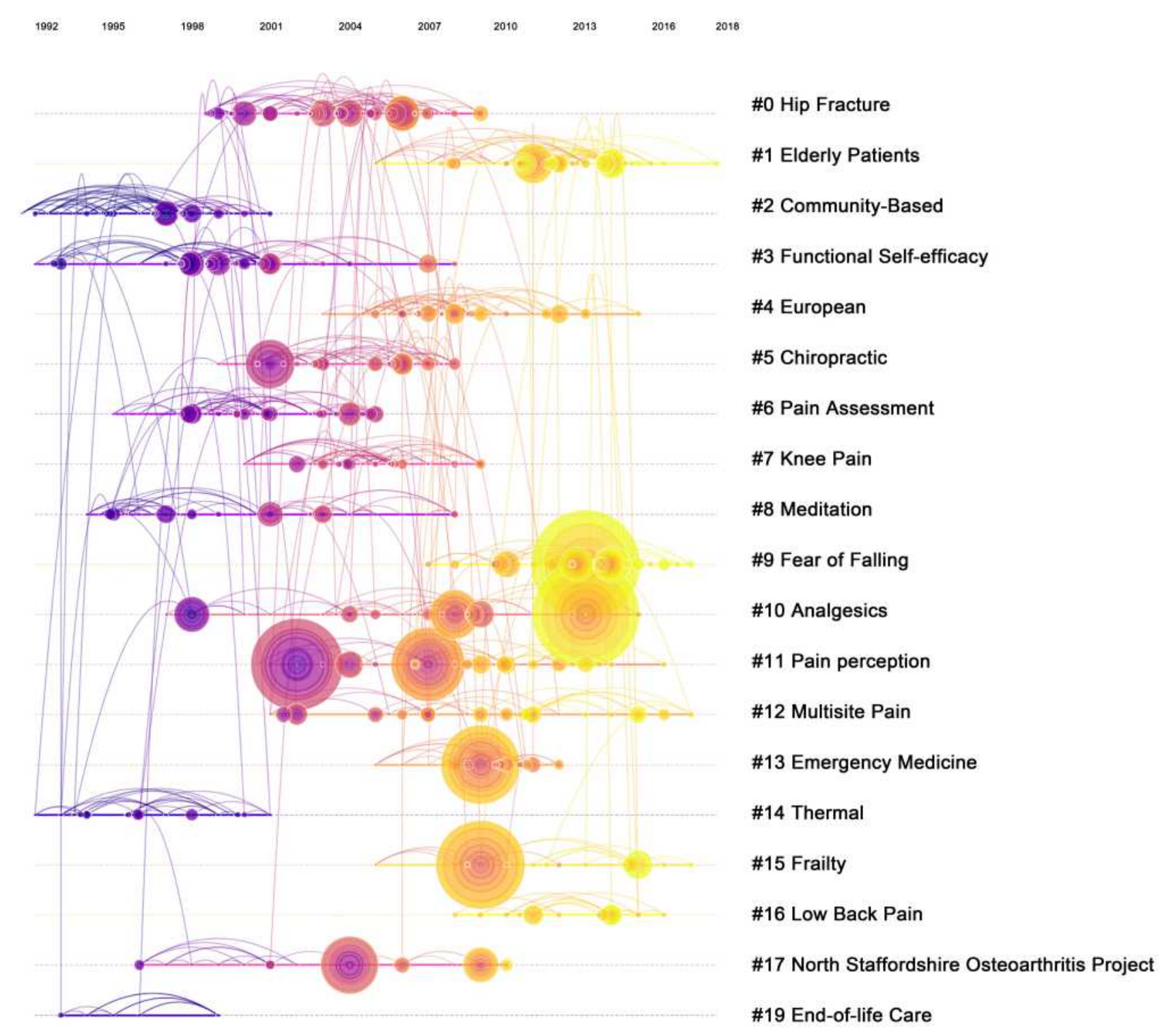

Figure 5 Co-citation map (timeline view) of references from publications on pain in the elderly. The size of the nodes reflects the number of publications or frequency; the larger the node, the higher the number of publications or frequency. The different colors within the nodes represent different times, the connection lines between the nodes reflect the relationship between the co-operation or co-citation, and the color of the line reflects the years when the co-operation or co-citation first appeared. Nodes with a larger centrality are more likely to become the key nodes in the network and are represented by purple on the node ring in the knowledge network map.

and $5.55 \%$ from 2000 to 2019 (Details of the coding rules for pain characteristics can be found in Supplement 4).

Experiments on humans or animals have been applied to pain-related studies on the elderly $(\mathrm{N}=110,5.23 \%)$. Whereas thermal (41.53\%) and mechanical (37.76\%) stimuli were the most frequently used types of pain stimuli, injury pain stimuli were used the least (1.43\%; Figure 9B).

\section{Discussion}

This review presents a bibliometric analysis of published articles on pain in the elderly over the last 20 years. A total of 2105 related articles were included, and the article types that made up the largest proportion of these publications are research articles $(84.89 \%, \mathrm{~N}=1787)$ and review articles (12.64\%, $\mathrm{N}=266)$. The overall number of articles published over time revealed an unstable upward trend, especially after 2012. This growth trend is consistent with previous growth trends observed in the fields of general pain, ${ }^{18,19}$ pediatric pain field, ${ }^{24}$ and overall biomedical publications. ${ }^{34}$

Bradford's law can be used to identify the "core" journals in a field. Table 7 shows the Bradford zones of scattering for articles on elderly pain. All journals were sorted by number of articles into three zones, each with approximately $33 \%$ of the total number of articles, and the number of journals in 
A

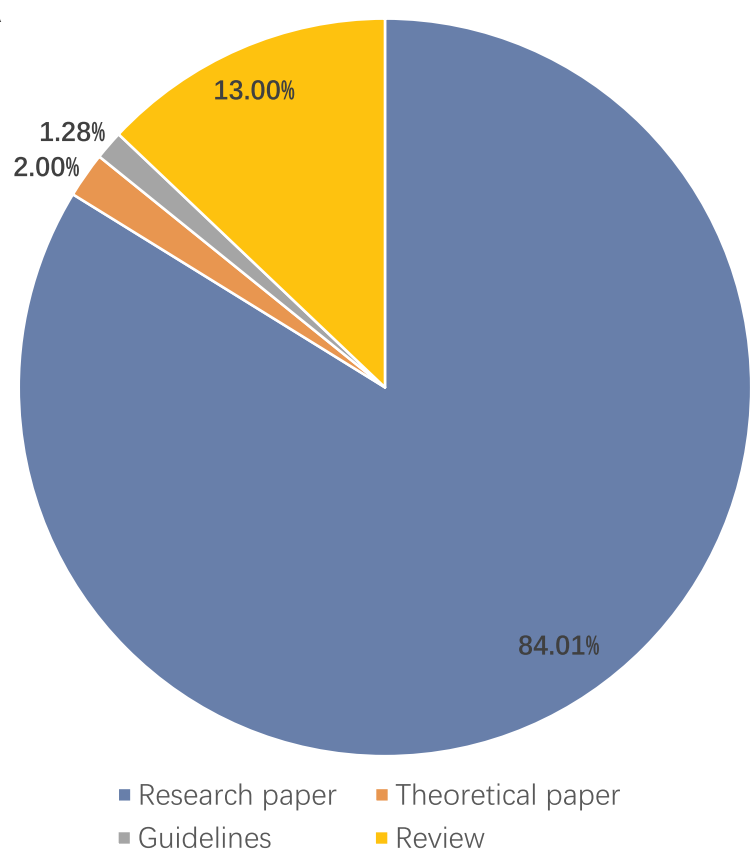

B

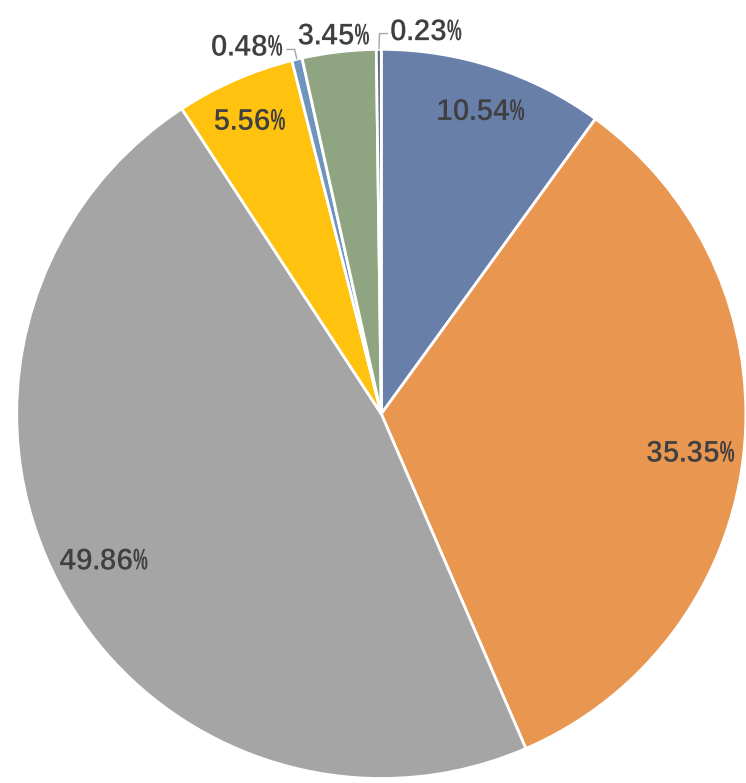

- Pain assesment

- Family factors

- Model development

- Pain intervention

- Biological factors

Figure 6 (A) Average percentage of each article type published from 2000 to 2019; (B) average percentage of topics discussed in articles published from 2000 to 2019.

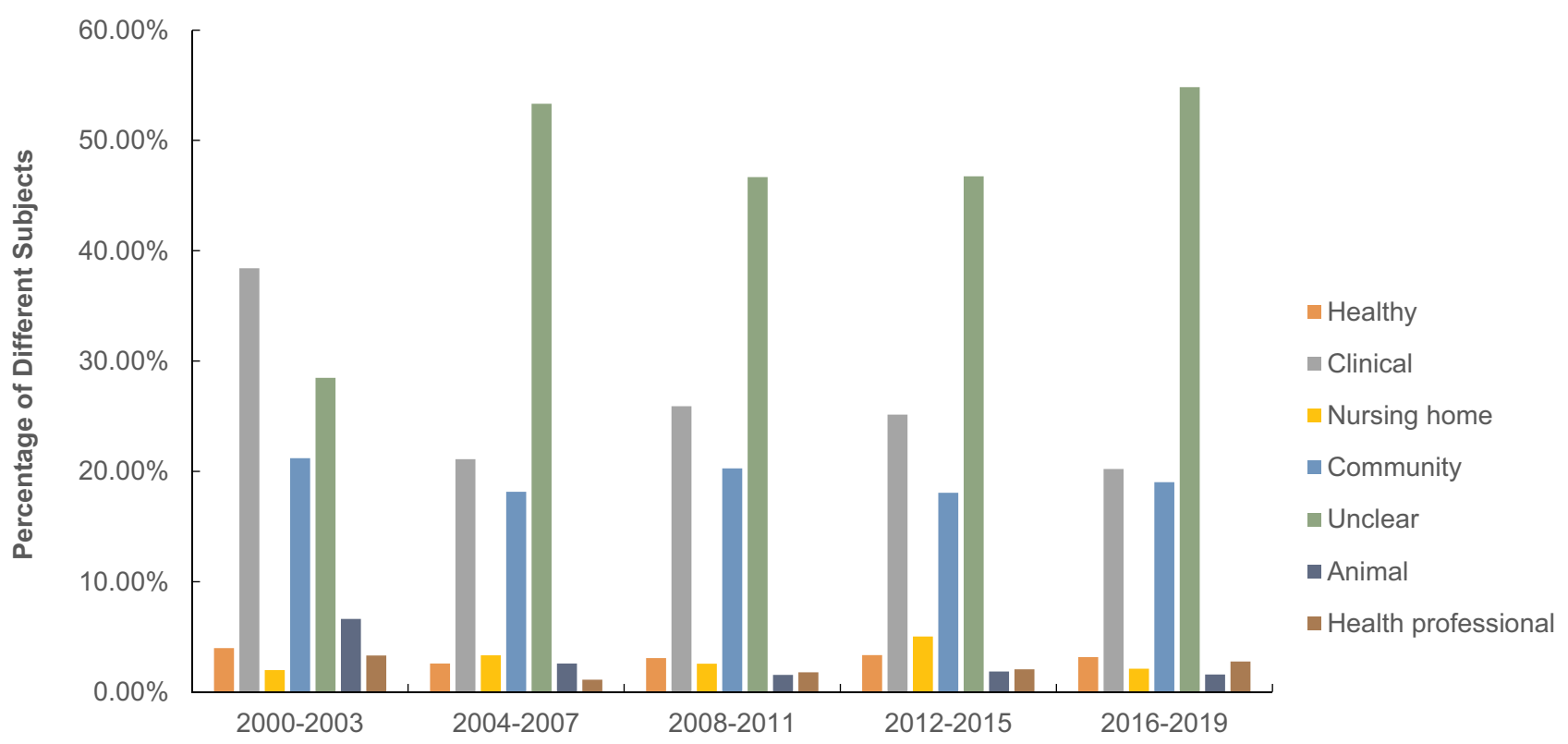

Figure 7 Trends of the percentage of subject type.

each zone was proportional to $1: \mathrm{n}: \mathrm{n}^{2}$. The top 20 journals accounted for $36.72 \%$ of the total number of publications in this field (773 publications), and the distribution of these articles is in accordance with Bradford's law. The IFs of all top 20 journals were below 10 . Journals with $3 \leq \mathrm{IF}<5$ contributed $20 \%$ of these articles, and journals with $5 \leq \mathrm{IF}<10$ contributed $10 \%$ of these articles. Pain Medicine published the greatest number of studies in the field of elderly pain, 
$120.00 \%$

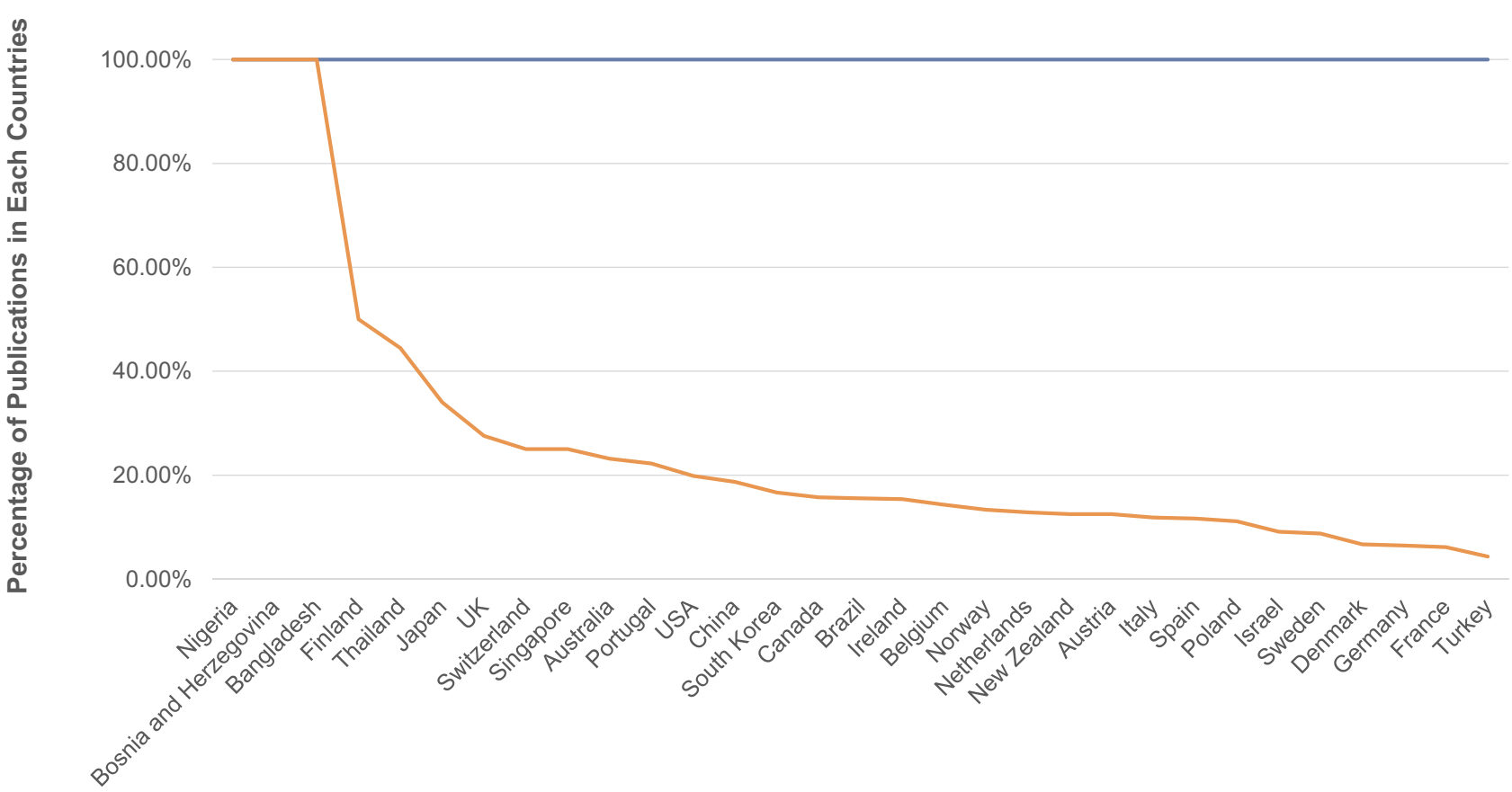

Figure 8 Percentage of community sample-based research studies amongst all research articles in each country (ie, in each country, the proportion of research studies in which subjects come from the community to the total number of studies in the country).
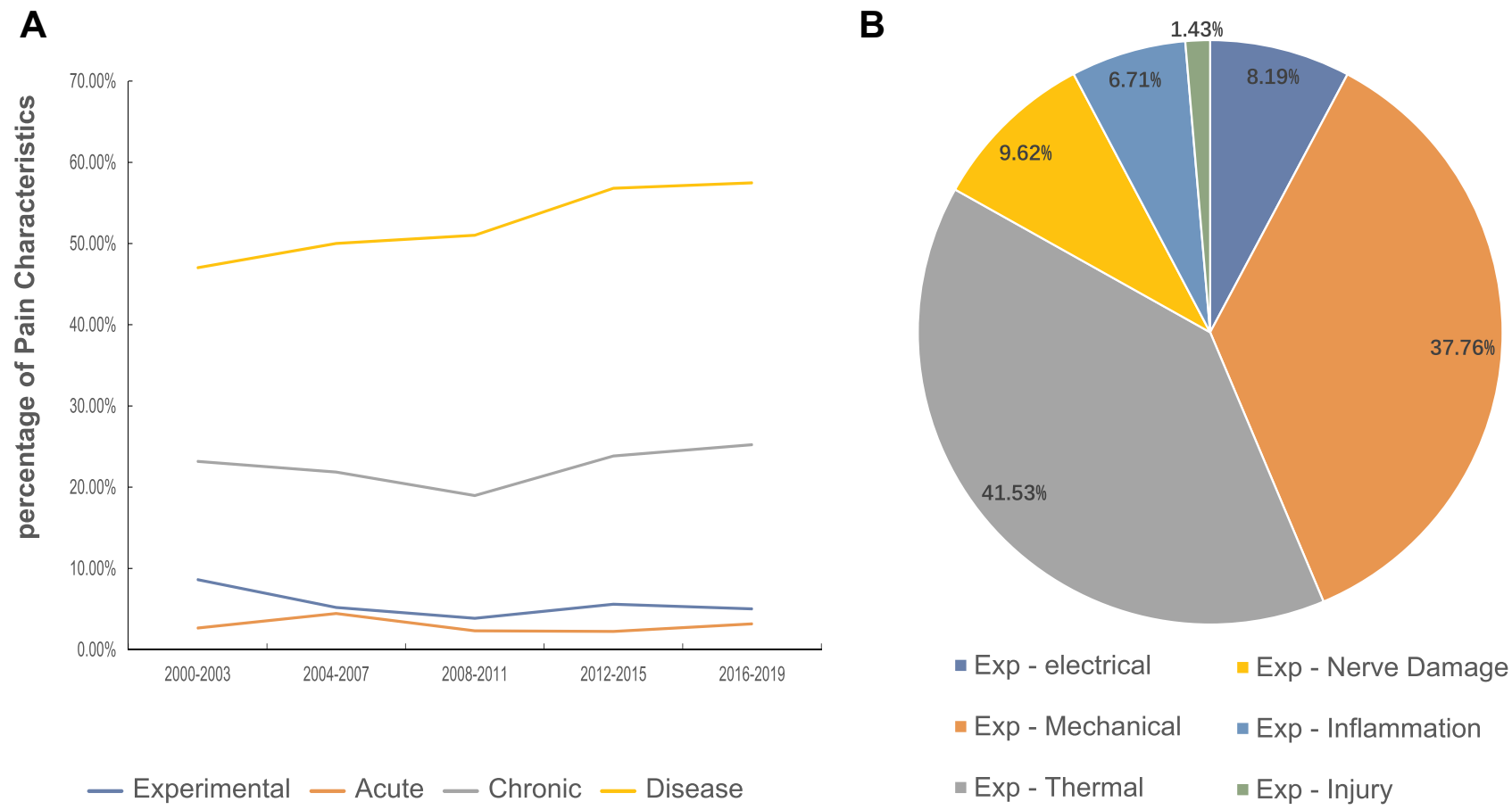

Figure 9 (A) Trends in the percentage of pain characteristics reported every 4 years; (B) average percentage of experimental designs reported every 4 years.

followed by PAIN, Journal of the American Geriatrics previous general pain studies. ${ }^{18,19}$ This ranking shows that Society, Pain Management Nursing and Drugs \& Aging. researchers in the field of pain in the elderly are highly Interestingly, these findings differ from the results of inclined to focus on elderly audiences in addition to the 
Table 7 Bradford's Law of Scattering for Journals That Published Articles on Elderly Pain Research from 2000 to 2019

\begin{tabular}{|l|c|c|}
\hline & $\mathbf{n}$ & $\mathbf{n} / \mathbf{N}(\%)$ \\
\hline Zonel & 17 & 3.18 \\
\hline Zone2 & 77 & 14.39 \\
\hline Zone3 & 441 & 82.43 \\
\hline
\end{tabular}

Notes: Each zone represents about 33\% of the total articles (2105); n, the number of journals in each zone; $\mathrm{N}$, the number of all journals (535).

broader pain field. Amongst the top 100 journals that published articles on pain, 26 were related to old age or aging and 14 focused on pain. This result is also consistent with previous findings. In terms of the disciplinary classification of journals, journals related to nursing $(\mathrm{N}=11)$ and rehabilitation $(\mathrm{N}=7)$ appeared to publish more articles on pain than other types of journals. Such a finding is consistent with the age characteristics of the elderly and a previous study. ${ }^{35}$

The United States appeared to be the primary source country of articles in this field with the most publications. In addition, 8 of the 20 articles with the highest citation scores and 11 of the top 20 journals in the number of published papers were from the United States. Although the choice of database may affect this specific result, this finding is similar to that of a previous general pain study. ${ }^{19}$ The top 10 countries with the largest number of published articles included were from three American countries, three Pacific countries and four European countries.

Our research found that researchers of pain in the elderly often focus on disease-related pain and chronic pain. These results are consistent with the general trend of adult pain literature, which mainly discusses chronic and disease-related pain. ${ }^{16,18}$ Previous studies reported that the most common types of pain in the elderly are low back or neck pain (65\%), musculoskeletal pain $(40 \%)$ and peripheral neuropathic pain (40\%). ${ }^{36-38}$ Similarly, the present study found that the types of pain receiving the greatest research attention are back pain $(12.30 \%)$, arthritis $(11.45 \%)$ and postsurgical pain $(4.66 \%)$. This observation may be related to the characteristics of this age group (such as the acceleration of aging and more susceptibility). Research on pain in the elderly has increased over time and may reflect the upward trends life expectancy, quality of life and social and economic development.

It is found that the most popular pain research topics include pain characteristics, intervention and assessment, which was supported by the fact that over half of the top 20 articles cited were related to pain characteristics. This result indicates that descriptions of pain in the elderly are a popular research topic in this field. These studies formed the basis for further basic or mechanistic studies and clinical intervention studies, and also indicated that evidence from animal and laboratory studies were not sufficient. Future preclinical research should be recommended to explore the related risk factors in the elderly and to establish animal models for mechanistic research. Experimental human research has been conducted, but these studies are relatively infrequent on account of reasons such as ethical challenges and experimental costs. In addition, we noticed that among the top 20 original articles in terms of total citation score or relative citation score, articles related to pain caused by arthritis received more attention (Supplement 5 and Supplement 6), but the citation score was relatively lower than the reviews of the same topic. This may imply that more innovative and breakthrough original research is needed. For musculoskeletal pain with a high prevalence in the elderly, such as low back pain, the citation score is significantly lower than that of original studies on this topic in the general population. ${ }^{39}$ Hence, the field of elderly pain deserves more appeal from future studies. According to our analysis of the keywords with strongest citation bursts and the subject categories in WoS, the strongest citation bursts changed from Neurosciences to the recent Multidisciplinary Sciences and Science \& Technology-Other Topics, as can be seen, the development of elderly pain research has gradually transitioned from phenomenon to mechanism and evolved from a single discipline to multiple disciplines.

There exist several strengths of value presented in this bibliometric analysis. First, the source of the literature was not limited to one journal, such as PAIN. Specifically, we collected articles from 535 journals to enrich the data. Second, we performed a detailed analysis of the general information, including author, year and journal, and abstracts of all included articles. Data indicators were not restricted to the properties such as the number of publications and citation scores. Therefore, the results of our analyses provide a rather precise description of publication trends. Furthermore, this study used two bibliometric analytical methods (ie, literature coding and CiteSpace V software) to produce more comprehensive analyses.

This review also possessed some limitations that may affect the interpretation of the results. Firstly, we merely used the SCI Expanded core collection of WoS to retrieve 
articles, and only those articles containing abstracts were included in this work. Moreover, non-English articles were excluded from the analysis. The adoption of a single database with English language restriction may probably lead to selection bias. We also excluded a number of conference abstracts that may describe novel content in the field. These omissions might lead to incomplete information acquisition. In addition, subjects were not grouped by age because the age range involved in the retrieved studies was fairly wide. Some articles did not mention details of their source of subjects in their abstracts.

\section{Conclusions}

Our study showed a significant increase in the number of elderly pain-related articles published in the past decades. This review, to a large extent, is a representative reflection of research trends on pain in the elderly. The research topics of articles included in this work generally focused on pain characteristics, pain intervention and assessment, chronic pain in the elderly, and the main types of pain included back pain, arthritis and postsurgical pain. Little is known about the transition from acute to chronic pain and the mechanisms of pain in the elderly population remain not clear. Therefore, future studies concerning chronic pain evolution and the underlying pain mechanisms are warranted.

\section{Acknowledgments}

The authors thank Haolan Liang, Shanshu Yang, Shanshan Xie and Feng Liu for their help with coding and data input. They also thank Linman Weng and Wangwang Yan for their help in image editing.

\section{Author Contributions}

All authors made substantial contributions to conception and design, acquisition of data, or analysis and interpretation of data; took part in drafting the article or revising it critically for important intellectual content; agreed to submit to the current journal; gave final approval of the version to be published; and agree to be accountable for all aspects of the work.

\section{Funding}

This study was supported by the grants from the Guangdong Hopson-Pearl River Education Development Foundation (No. H20190116202012724), the Shanghai Key Lab of Human Performance (Shanghai University of Sport) (No. 11DZ2261100); The Guangzhou Municipal Technological Major Tackling Plan Modern Industrial
Technology Project of China (No. 201802010039), and the scientific and technological research program of the Shanghai Science and Technology Committee (No. 19080503100).

\section{Disclosure}

The authors have no conflicts of interest to declare.

\section{References}

1. United Nations, Department of Economic and Social Affairs, Population Division. World population prospects 2019: ten key findings; 2019. Available from: https://population.un.org/wpp/ Publications/Files/WPP2019_10KeyFindings.pdf. Accessed February 4, 2021.

2. Mattiuzzi C, Lippi G. Worldwide disease epidemiology in the older persons. Eur Geriatr Med. 2020;11(1):147-153. doi:10.1007/s41999019-00265-2

3. Blyth FM, Noguchi N. Chronic musculoskeletal pain and its impact on older people. Best Pract Res Clin Rheumatol. 2017;31 (2):160-168. doi:10.1016/j.berh.2017.10.004

4. Guerard EJ, Cleary JF. Managing cancer pain in older adults. Cancer J. 2017;23(4):242-245. doi:10.1097/00130404-201707000-00009

5. Baker TA, Clay OJ, Johnson-Lawrence V, et al. Association of multiple chronic conditions and pain among older black and white adults with diabetes mellitus. BMC Geriatr. 2017;17(1):255. doi:10.1186/ s12877-017-0652-8

6. Abdulla A, Adams N, Bone M, et al. Guidance on the management of pain in older people. Age Ageing. 2013;42(Suppl 1):i1-i57. doi:10.1093/ageing/afs199

7. Kozak-Szkopek E, Broczek K, Slusarczyk P, et al. Prevalence of chronic pain in the elderly Polish population - results of the PolSenior study. Arch Med Sci. 2017;5(5):1197-1206. doi:10.5114/ aoms.2015.55270

8. Steingrímsdóttir ÓA, Landmark T, Macfarlane GJ, et al. Defining chronic pain in epidemiological studies: a systematic review and meta-analysis. PAIN. 2017;158(11):2092-2107. doi:10.1097/j. pain.0000000000001009

9. King S, Chambers CT, Huguet A, et al. The epidemiology of chronic pain in children and adolescents revisited: a systematic review. PAIN. 2011;152(12):2729-2738. doi:10.1016/j.pain.2011.07.016

10. Jones MR, Ehrhardt KP, Ripoll JG, et al. Pain in the elderly. Curr Pain Headache Rep. 2016;20(4):23. doi:10.1007/s11916-016-0551-2

11. Malec M, Shega JW. Pain management in the elderly. Med Clin North Am. 2015;99(2):337-350. doi:10.1016/j.mcna.2014.11.007

12. Manion J, Waller MA, Clark T, et al. Developing modern pain therapies. Front Neurosci. 2019;13:1370. doi:10.3389/ fnins.2019.01370

13. Thompson DF, Walker CK. A descriptive and historical review of bibliometrics with applications to medical sciences. Pharmacotherapy. 2015;35(6):551-559. doi:10.1002/phar.1586

14. Roldan-Valadez E, Salazar-Ruiz SY, Ibarra-Contreras R, et al. Current concepts on bibliometrics: a brief review about impact factor, Eigenfactor score, CiteScore, SCImago Journal Rank, Source-Normalised Impact per Paper, H-index, and alternative metrics. Ir J Med Sci. 2019;188(3):939-951. doi:10.1007/s11845018-1936-5

15. Cooper ID. Bibliometrics basics. J Med Libr Assoc. 2015;103 (4):217-218. doi:10.3163/1536-5050.103.4.013

16. Chuang KY, Ho YS. A bibliometric analysis on top-cited articles in pain research. Pain Med. 2014;15(5):732-744. doi:10.1111/ pme. 12308 
17. Dubner R. A bibliometric analysis of the Pain journal as a representation of progress and trends in the field. PAIN. 2009;142 (1):9-10. doi:10.1016/j.pain.2009.01.003

18. Mogil JS, Simmonds K, Simmonds MJ. Pain research from 1975 to 2007: a categorical and bibliometric meta-trend analysis of every Research Paper published in the journal, Pain. PAIN. 2009;142 (1):48-58. doi:10.1016/j.pain.2008.11.012

19. Robert C, Wilson CS, Donnadieu S, et al. Evolution of the scientific literature on pain from 1976 to 2007. Pain Med. 2010;11(5):670-684. doi:10.1111/j.1526-4637.2010.00816.x

20. Wang XQ, Peng MS, Weng LM, et al. Bibliometric study of the comorbidity of pain and depression research. Neural Plast. 2019;2019:1657498. doi:10.1155/2019/1657498

21. Zheng K, Wang X. Publications on the association between cognitive function and pain from 2000 to 2018: a bibliometric analysis using CiteSpace. Med Sci Monit. 2019;25:8940-8951. doi:10.12659/ MSM.917742

22. Robert C, Wilson CS, Lipton RB, et al. Growth of headache research: a 1983-2014 bibliometric study. Cephalalgia. 2017;37 (13):1299-1309. doi:10.1177/0333102416678636

23. Weng LM, Zheng YL, Peng MS, et al. A bibliometric analysis of nonspecific low back pain research. Pain Res Manag. 2020;2020:5396734. doi:10.1155/2020/5396734

24. Caes L, Boerner KE, Chambers CT, et al. A comprehensive categorical and bibliometric analysis of published research articles on pediatric pain from 1975 to 2010. PAIN. 2016;157(2):302-313. doi:10.1097/j.pain.0000000000000403

25. Chen C. Searching for intellectual turning points: progressive knowledge domain visualization. Proc Natl Acad Sci U S A. 2004;101 (Suppl1):5303-5310. doi:10.1073/pnas.0307513100

26. Liang C, Luo A, Zhong Z. Knowledge mapping of medication literacy study: a visualized analysis using CiteSpace. SAGE Open Med. 2018;6:2050312118800199. doi:10.1177/2050312118800199

27. Chen C, Dubin R, Kim MC. Orphan drugs and rare diseases: a scientometric review (2000 - 2014). Expert Opin Orphan Drugs. 2014;2(7):709-724. doi:10.1517/21678707.2014.920251

28. Zheng KY, Dai GY, Lan Y, et al. Trends of repetitive transcranial magnetic stimulation from 2009 to 2018: a bibliometric analysis. Front Neurosci. 2020;14:106. doi:10.3389/fnins.2020.00106

29. Liang YD, Li Y, Zhao J, et al. Study of acupuncture for low back pain in recent 20 years: a bibliometric analysis via CiteSpace. J Pain Res. 2017;10:951-964. doi:10.2147/JPR.S132808

30. Crowe M, Gillon D, Jordan J, et al. Older peoples' strategies for coping with chronic non-malignant pain: a qualitative meta-synthesis. Int J Nurs Stud. 2017;68:40-50. doi:10.1016/j.ijnurstu.2016.12.009

31. Niknejad B, Bolier R, Henderson CR, et al. Association between psychological interventions and chronic pain outcomes in older adults: a systematic review and meta-analysis. JAMA Intern Med. 2018;178(6):830-839. doi:10.1001/jamainternmed.2018.0756

32. Hadjistavropoulos T, Herr K, Prkachin KM, et al. Pain assessment in elderly adults with dementia. Lancet Neurol. 2014;13 (12):1216-1227. doi:10.1016/S1474-4422(14)70103-6

33. Makris UE, Abrams RC, Gurland B, et al. Management of persistent pain in the older patient: a clinical review. JAMA. 2014;312 (8):825-836. doi:10.1001/jama.2014.9405

34. Zhao J, Yu G, Cai M, et al. Bibliometric analysis of global scientific activity on umbilical cord mesenchymal stem cells: a swiftly expanding and shifting focus. Stem Cell Res Ther. 2018;9(1):32. doi:10.1186/s13287-018-0785-5

35. Damar HT, Bilik O, Ozdagoglu G, et al. Scientometric overview of nursing research on pain management. Rev Lat Am Enfermagem. 2018;26:e3051. doi:10.1590/1518-8345.2581.3051

36. Denard PJ, Holton KF, Miller J, et al. Back pain, neurogenic symptoms, and physical function in relation to spondylolisthesis among elderly men. Spine J. 2010;10(10):865-873. doi:10.1016/j. spinee.2010.07.004
37. Mailis-Gagnon A, Nicholson K, Yegneswaran B, et al. Pain characteristics of adults 65 years of age and older referred to a tertiary care pain clinic. Pain Res Manag. 2008;13(5):389-394. doi:10.1155/2008/ 541963

38. Molton IR, Terrill AL. Overview of persistent pain in older adults. Am Psychol. 2014;69(2):197-207. doi:10.1037/a0035794

39. Hill JC, Whitehurst DG, Lewis M, et al. Comparison of stratified primary care management for low back pain with current best practice (STarT Back): a randomised controlled trial. Lancet. 2011;378 (9802):1560-1571. doi:10.1016/S0140-6736(11)60937-9

40. Peat G, McCarney R, Croft P. Knee pain and osteoarthritis in older adults: a review of community burden and current use of primary health care. Ann Rheum Dis. 2001;60(2):91-97. doi:10.1136/ ard.60.2.91

41. Messier SP, Loeser RF, Miller GD, et al. Exercise and dietary weight loss in overweight and obese older adults with knee osteoarthritis: the arthritis, diet, and activity promotion trial. Arthritis Rheum. 2004;50 (5):1501-1510. doi:10.1002/art.20256

42. Blagojevic M, Jinks C, Jeffery A, et al. Risk factors for onset of osteoarthritis of the knee in older adults: a systematic review and meta-analysis. Osteoarthritis Cartilage. 2010;18(1):24-33. doi:10.1016/j.joca.2009.08.010

43. Lin EH, Katon W, Von Korff M, et al. Effect of improving depression care on pain and functional outcomes among older adults with arthritis: a randomized controlled trial. JAMA. 2003;290(18):2428-2429. doi:10.1001/jama.290.18.2428

44. Hadjistavropoulos T, Herr K, Turk DC, et al. An interdisciplinary expert consensus statement on assessment of pain in older persons. Clin J Pain. 2007;23(1 Suppl):S1-S43. doi:10.1097/AJP.0b013e31802be869

45. Thomas E, Peat G, Harris L, et al. The prevalence of pain and pain interference in a general population of older adults: cross-sectional findings from the North Staffordshire Osteoarthritis Project (NorStOP). PAIN. 2004;110(1):361-368. doi:10.1016/j.pain.2004.04.017

46. Herr KA, Spratt K, Mobily PR, et al. Pain intensity assessment in older adults: use of experimental pain to compare psychometric properties and usability of selected pain scales with younger adults. Clin J Pain. 2004;20(4):207-219. doi:10.1097/00002508-200407000-00002

47. Helme RD, Gibson SJ. The epidemiology of pain in elderly people. Clin Geriatr Med. 2001;17(3):417-v. doi:10.1016/S0749-0690(05) 70078-1

48. Herr K, Bjoro K, Decker S. Tools for assessment of pain in nonverbal older adults with dementia: a state-of-the-science review. J Pain Symptom Manage. 2006;31(2):170-192. doi:10.1016/j.jpainsymman.2005.07.001

49. Morone NE, Greco CM, Weiner DK. Mindfulness meditation for the treatment of chronic low back pain in older adults: a randomized controlled pilot study. PAIN. 2008;134(3):310-319. doi:10.1016/j. pain.2007.04.038

50. Jones CA, Voaklander DC, Johnston DW, et al. The effect of age on pain, function, and quality of life after total hip and knee arthroplasty. Arch Intern Med. 2001;161(3):454 460. doi:10.1001/archinte.161.3.454

51. Solomon DH, Rassen JA, Glynn RJ, et al. The comparative safety of analgesics in older adults with arthritis. Arch Intern Med. 2010;170 (22):1968-1976. doi:10.1001/archinternmed.2010.391

52. Gibson SJ, Helme RD. Age-related differences in pain perception and report. Clin Geriatr Med. 2001;17(3):433-456, v-vi. doi:10.1016/ S0749-0690(05)70079-3

53. Leveille SG, Jones RN, Kiely DK, et al. Chronic musculoskeletal pain and the occurrence of falls in an older population. JAMA. 2009;302(20):2214-2221. doi:10.1001/jama.2009.1738

54. Gagliese L, Weizblit N, Ellis W, et al. The measurement of postoperative pain: a comparison of intensity scales in younger and older surgical patients. PAIN. 2005;117(3):412-420. doi:10.1016/j. pain.2005.07.004

55. Gibson SJ, Farrell M. A review of age differences in the neurophysiology of nociception and the perceptual experience of pain. Clin J Pain. 2004;20(4):227-239. doi:10.1097/00002508-200407000-00004 
56. Lautenbacher S, Kunz M, Strate P, et al. Age effects on pain thresholds, temporal summation and spatial summation of heat and pressure pain. PAIN. 2005;115(3):410-418. doi:10.1016/j. pain.2005.03.025

57. Silverwood V, Blagojevic-Bucknall M, Jinks C, et al. Current evidence on risk factors for knee osteoarthritis in older adults: a systematic review and meta-analysis. Osteoarthritis Cartilage. 2015;23(4):507-515. doi:10.1016/j.joca.2014.11.019

58. Patel KV, Guralnik JM, Dansie EJ, et al. Prevalence and impact of pain among older adults in the United States: findings from the 2011 National Health and Aging Trends Study. PAIN. 2013;154 (12):2649-2657. doi:10.1016/j.pain.2013.07.029

59. Avidan MS, Maybrier HR, Abdallah AB, et al. Intraoperative ketamine for prevention of postoperative delirium or pain after major surgery in older adults: an international, multicentre, double-blind, randomised clinical trial. Lancet. 2017;390(10091):267-275. doi:10.1016/S0140-6736(17)31467-8
60. Edwards RR, Fillingim RB, Ness TJ. Age-related differences in endogenous pain modulation: a comparison of diffuse noxious inhibitory controls in healthy older and younger adults. PAIN. 2003;101 (1):155-165. doi:10.1016/S0304-3959(02)00324-X

61. Langan SM, Smeeth L, Margolis DJ, et al. Herpes zoster vaccine effectiveness against incident herpes zoster and post-herpetic neuralgia in an older US population: a cohort study. PLoS Med. 2013;10 (4):e1001420. doi:10.1371/journal.pmed.1001420

62. Morone NE, Greco CM, Moore CG, et al. A mind-body program for older adults with chronic low back pain: a randomized clinical trial. JAMA Intern Med. 2016;176(3):329-337. doi:10.1001/ jamainternmed.2015.8033

63. Vitiello MV, Rybarczyk B, Von Korff M, et al. Cognitive behavioral therapy for insomnia improves sleep and decreases pain in older adults with co-morbid insomnia and osteoarthritis. J Clin Sleep Med. 2009;5(4):355-362. doi:10.5664/jcsm.27547

\section{Publish your work in this journal}

The Journal of Pain Research is an international, peer reviewed, open access, online journal that welcomes laboratory and clinical findings in the fields of pain research and the prevention and management of pain. Original research, reviews, symposium reports, hypothesis formation and commentaries are all considered for publication. The manuscript management system is completely online and includes a very quick and fair peer-review system, which is all easy to use. Visit http:// www.dovepress.com/testimonials.php to read real quotes from published authors. 